\title{
ANALISIS FAKTOR-FAKTOR DALAM KUALITAS KEHIDUPAN KERJA (QUALITY WORK LIFE) DI FAKULTAS EKONOMI UNIVERSITAS NEGERI JAKARTA
}

\author{
Umi Widyastuti* \\ Dedi Purwana*
}

\begin{abstract}
Many factors determine the meaning of quality of work life (QWL). This research reviews the factors of QWL based on models and past research. The factors of QWL discussed are balance between life and non life, the work itself, skill utilization, working condition, job involvement, co-worker relationship, promotion, salary and supervisory. Confirmatory Factor Analysis is used to determine dominant factors of QWL. This research concludes that all the factors we discussed have the value of Keiser Meyers Oklin Measure of Sampling Adequacy more than 0.5, except salary. It means that eight factors which determine QWL are balance between life and non life, the work itself, skill utilization, working condition, job involvement, coworker relationship, promotion and supervisory. After varimax rotation process and based on criteria eigenvalue more than 1, this research has formed two component from all the factors. Component 1 consist of the factor: balance between life and non life, working condition, promotion and supervisory. And component 2 consist of the factor: work itself, skill utilization, job involvement and co-worker relationship.
\end{abstract}

\section{PENDAHULUAN}

Saat ini organisasi semakin memahami pentingnya mempertahankan loyalitas karyawan, sebagai salah satu sumber daya untuk mengembangkan organisasi. Salah satu cara yang dapat dilakukan oleh organisasi untuk mempertahankan loyalitas karyawannya adalah dengan meningkatkan kualitas kehidupan kerjanya. Perusahaan mengalami kesulitan untuk membuat program yang tepat, yang dapat memenuhi kebutuhan karyawan akan kualitas kehidupan kerjanya. Hal ini

\footnotetext{
* Umi Widyastuti dan Dedi Purwana. Dosen
} Fakultas Ekonomi Universitas Negeri Jakarta disebabkan karena kualitas kehidupan kerja sangat dipengaruhi oleh banyak faktor, dan setiap individu memiliki persepsi dan nilai yang berbeda-beda satu dengan lainnya dalam mempersepsikan kualitas kehidupan kerjanya.

Untuk memenuhi berbagai macam kebutuhan, maka bekerja adalah salah satu pilihan yang dapat dilakukan oleh manusia dewasa. Memiliki pekerjaan menjadi salah satu faktor yang penting yang dapat menjadi jalan keluar bagi proses pemenuhan kebutuhan. Dengan bekerja, seseorang mendapat imbalan yang beraneka ragam, dari mulai gaji, kesejahteraan, bahkan sampai pada 
pujian dan status dapat diperoleh. Kondisi inilah yang membuat setiap orang memiliki tujuan dan harapan, dan persepsi yang berbeda dalam bekerja.

Proses

mempersepsikan seseorang kehidupan pekerjaannya dapat mempengaruhi kualitas kehidupan mereka secara menyeluruh. Secara umum manusia memiliki kebutuhan yang bertingkat dan dalam setiap tingkatan ini setiap orang memiliki persepsi dan nilai yang berbeda berkaitan dengan kehidupan pekerjaannya, tergantung pada bagaimana orientasi seseorang dalam memenuhi kebutuhannya. Semakin tinggi tingkatan kebutuhan yang harus dipenuhi oleh seseorang maka dia memiliki persepsi dan nilai yang lebih tinggi terhadap kehidupan pekerjaannya. Individu mempersepsikan dan menilai pekerjaannya secara positif, jika dia menganggap bahwa pekerjaannya dapat memenuhi kebutuhankebutuhan hidupnya. Dan sebaliknya seseorang mempersepsikan dan menilai pekerjaannya secara negatif jika pekerjaannya tersebut belum dapat atau bahkan tidak mampu memenuhi kebutuhan-kebutuhan hidupnya.

Disisi lain, pengalaman bekerja dan perasaan dalam bekerja, juga menjadi salah satu faktor yang dapat mempengaruhi kualitas hidup seseorang. Akhir-akhir ini kecenderungan seseorang untuk meningkatkan kualitas hidup mereka melalui pengalaman kerja menjadi semakin tinggi. Bahkan beberapa penelitian membuktikan bahwa profesi seseorang dapat mempengaruhi persepsi dan nilai yang dianut seseorang berkaitan dengan kualitas hidupnya. Hal ini berarti bahwa untuk profesi yang berbeda meski dalam satu lembaga, seseorang bisa memiliki persepsi yang berbeda dengan orang lain dalam menilai kualitas kehidupan kerjanya. Fakultas Ekonomi Universitas Negeri Jakarta merupakan sebuah lembaga yang memiliki komitmen tinggi dalam mengembangkan sumber daya manusia yang dimiliki dalam rangka meningkatkan kualitas kehidupan kerja karyawannya, yang berbeda latar belakang pendidikan, dan berbeda profesi dalam hal ini sebagai staf pengajar dan tenaga administrasi. Oleh karena itu, diperlukan sebuah kajian yang mendalam untuk menganalisis factorfaktor yang menentukan kualitas kehidupan kerja karyawannya. Penelitian ini dilakukan untuk mendapatkan gambaran mengenai persepsi karyawan di Fakultas Ekonomi Universitas Negeri Jakarta terhadap faktor-faktor yang menentukan kualitas kehidupan kerja mereka. Berdasarkan hal tersebut diatas maka dilakukan penelitian tentang "Analisis Faktor-Faktor dalam Kualitas Kehidupan Kerja (Quality of Work Life) di Fakultas Ekonomi Universitas Negeri Jakarta."

\section{Perumusan Masalah}

Apakah faktor-faktor yang menentukan kualitas kehidupan kerja (Quality of Work Life) karyawan Fakultas Ekonomi Universitas Negeri Jakarta? 


\section{Tujuan Penelitian}

Penelitian ini bertujuan untuk mengetahui faktor-faktor yang menentukan kualitas kehidupan kerja di lingkungan Fakultas ekonomi Universitas Negeri Jakarta.

\section{KAJIAN TEORI}

Kualitas kehidupan kerja merupakan suatu konsep atau falsafah manajemen dalam rangka perbaikan kualitas sumber daya manusia, yang telah dikenal sejak decade tujuh puluhan. Pada saat itu kualitas kehidupan kerja diartikan secara sempit yaitu sebagai teknik manajemen yang mencakup gugus kendali mutu, perkayaan pekerjaaan, suatu pendekatan untuk bernegosiasi dengan serikat pekerja, upaya manajemen untuk memelihara kebugaran mental para karyawan, hubungan industrial yang serasi, manajemen yang partisipatif dan salah satu bentuk intervensi dalam pengembangan organisasional. Menurut Wayne (1992) terdapat dua pandangan mengenai maksud dari kualitas kehidupan kerja. Pertama, bahwa kualitas kehidupan kerja (Quality Work of Life) adalah sejumlah keadaan dan praktek dari tujuan organisasi, diantaranya adalah pengayaan pekerjaan, penyeliaan yang demokratis, keterlibatan kerja dan kondisi pekerjaan yang aman. Kedua, mendefinisikan kualitas kehidupan kerja (Quality Work of Life) sebagai persepsi karyawan terhadap pekerjaannya diantaranya karyawan merasa aman, merasakan kepuasan kerja dan mampu berkembang.

\section{Dalam} perkembangan selanjutnya kualitas kehidupan kerja merupakan salah satu bentuk falsafah yang diterapkan oleh manajemen dalam mengelola organisasi pada umumnya dan sumber daya manusia pada khususnya. Menurut Ari Husnawati (2006), sebagai filsafat, kualitas kehidupan kerja merupakan cara pandang manajemen tentang manusia, pekerja dan organisasi. Unsur-unsur pokok dalam filsafat tersebut ialah: kepedulian manajemen tentang dampak pekerjaan pada manusia, efektifitas organisasi serta pentingnya para karyawan dalam pemecahan keputusan teutama yang menyangkut pekerjaan, karier, penghasilan dan nasib mereka dalam pekerjaan.

Menurut Loscocco and Roschelle (1991), pengukuran kualitas kehidupan kerja (Quality Work of Life) ditentukan oleh sikap individu terhadap komponen dalam kualitas kehidupan kerja (Quality Work of Life). Dalam hal ini sikap karyawan terhadap pekerjaannya dipengaruhi oleh karakteristik pekerjaan itu sendiri. Selanjutnya sikap tersebut dapat menentukan kebahagiaan hidup karyawan dan efektifitas karyawan dalam menjalankan pekerjaan.

Menurut Hackman dan Oldhams (1980), konstruk kualitas kehidupan kerja berkaitan dengan adanya interaksi antara lingkungan kerja dengan kebutuhan hidup seseorang. Lingkungan kerja dapat memenuhi kebutuhan karyawan sehingga mendorong tercapainya kualitas kehidupan kerja yang baik. 
Dalam hal ini seorang karyawan merasa terpuaskan kebutuhannya pada saat karyawan mendapatkan penghargaan dari organisasinya seperti kompensasi, promosi, pengakuan dan pengembangan kompetensi. Sejalan dengan hal tersebut Lawler mendefinisikan kualitas kehidupan kerja sebagai bagian dari karakteristik pekerjaan dan lingkungan pekerjaan. Dimensi keseluruhan dalam kualitas kehidupan kerja di organisasi adalah untuk memperbaiki kesejahteraan dan produktivitas karyawan yang dapat dilakukan melalui desain pekerjaan.

Pengertian kualitas kehidupan kerja menurut Dessler (2003) adalah keadaan yang dirasakan para pegawai untuk dapat memenuhi kebutuhan yang penting bagi mereka dengan bekerja dalam organisasi. Kemampuan untuk melakukan hal tersebut tergantung pada apakah terdapat perlakuan yang adil dan sportif terhadap pegawai, kesempatan bagi pegawai untuk menggunakan kemampuan penuh, komunikasi terbuka dengan saling mempercayai di antara rekan kerja, kesempatan bagi semua pegawai untuk mengembangkan diri, kesempatan bagi pegawai untuk berperan aktif dalam pengambilan keputusan yang melibatkan pekerjaan mereka, kompensasi yang cukup adil, serta lingkungan yang aman dan sehat.

Menurut Walton dalam Rose et al (2006), terdapat delapan komponen utama yang berkaitan dengan kualitas kehidupan kerja (Quality Work of Life) yaitu (1) kompensasi yang cukup dan adil (2) kondisi pekerjaan yang sehat dan aman (3) kesempatan untuk menggunakan dan mengembangkan kapasitas yang dimiliki oleh karyawan, (4) kesempatan untuk pertumbuhan berkelanjutan, (5) integrasi sosial dalam organisasi, konstitusionalisme dalam pekerjaan, (7) keseimbangan antara kehidupan kerja dan kehidupan di luar pekerjaan, (8) relevansi sosial dalam kehidupan kerja.

Kualitas kehidupan kerja (Quality of work life) diartikan sebagai kepuasan akan kebutuhan manusia. Menurut Sirgy et al (2001), factor kunci dalam kualitas kehidupan kerja adalah adanya kepuasan dalam kebutuhan akan pekerjaan itu sendiri, kepuasan dalam kebutuhan akan lingkungan pekerjaan, kepuasan dalam kebutuhan akan hubungannya dengan atasan, kepuasan akan kebutuhan pengembangan diri dan komitmen organisasi. Sedangkan menurut Danna dan Giffin (1999), dalam hal ini kualitas kehidupan kerja (Quality of Work Life) tidak hanya mencakup factor-faktor yang berkaitan dengan pekerjaan seperti kepuasan kerja terhadap gaji yang adil, kepuasan terhadap hubungan dengan rekan kerja tetapi juga factor yang berkaitan dengan kebahagiaan hidup dan kesejahteraan hidup seseorang.

Menurut The European Foundation for the Improvement of Living and Working Condition (EWON) dalam Guna dan Maimunah (2008), kualitas kehidupan kerja merupakan sebuah konstruk multi dimensi yang 
terdiri dari sejumlah faktor yang saling berhubungan yang memerlukan pertimbangan yang sangat teliti dalam membuat konsep dan pengukurannya. Kualitas kehidupan kerja memiliki keterkaitan dengan kepuasan kerja, keterlibatan kerja, motivasi, produktivitas, kesehatan, keamanan dan kesejahteraan, keamanan kerja, pengembangan kompetensi dan keseimbangan antara pekerjaan dan kehidupan di luar pekerjaan.

Dalam penelitian yang dilakukan Guna dan Maimunah (2008), faktor-faktor tersebut diyakini cocok dan sesuai untuk wilayah Asia pada umumnya dan Malaysia khususnya. Guna dan Maimunah melakukan penelitian dengan menggunakan sampel tenaga IT profesional, dimensi kualitas kehidupan kerja diantaranya meliputi kesehatan dan kesejahteraan (health and well being), keamanan kerja (job security), kepuasan kerja (job satisfaction), pengembangan kompetensi (competence development) dan keseimbangan antara pekerjaan dengan kehidupan di luar pekerjaan (the balance between work with non-work life).

\section{METODOLOGI PENELITIAN}

Variabel dalam penelitian ini adalah kualitas kehidupan kerja (Quality Work of Life). Kualitas Kehidupan Kerja (Quality Work of Life) adalah suatu keadaan yang mencerminkan sikap individu terhadap pekerjaannya yang dapat menentukan kebahagiaan hidup seseorang. Kualitas kehidupan kerja
(Quality Work of Life) adalah persepsi karyawan terhadap faktor-faktor dalam pekerjaannya yang meliputi keseimbangan antara pekerjaan dengan kehidupan di luar pekerjaan (balance between life and non life), pekerjaan itu sendiri (the work itself), pengembangan ketrampilan (skill utilization), lingkungan kerja (working condition), keterlibatan kerja (job involvement), hubungan dengan rekan kerja (co-worker relationship), kesempatan promosi (promotion), gaji (salary) dan pengawasan (supervisors).

Populasi dalam penelitian ini adalah seluruh karyawan tetap Fakultas Ekonomi baik karyawan edukatif maupun karyawan administratif yang berjumlah 102 orang. Dari populasi tersebut kemudian diambil sampel sebanyak 83 orang dengan menggunakan teknik pengambilan sampel simple random sampling. Namun dari 83 sampel yang ada, hanya 76 data yang dapat dianalisis.

Data dalam penelitian ini berupa data primer yang dikumpulkan dengan menggunakan instrumen kuisioner. Instrumen yang digunakan adalah angket yang disusun berdasarkan faktor-faktor (indikator) dalam variabel kualitas kehidupan kerja (Quality Work of Life). Untuk mengolah setiap variabel dalam analisis data yang diperoleh, disediakan beberapa alternatif jawaban dan skor dari setiap butir pertanyaan. Alternatif jawaban disesuaikan dengan skala Likert, yaitu : Sangat setuju (SS), Setuju (S), 
Ragu-ragu (RR), Tidak setuju (TS), Sangat tidak setuju (STS).

Dalam hal ini, responden diminta untuk menjawab pernyataanpernyataan yang bersifat positif dan negatif. Pilihan jawaban responden diberi nilai $5 \square$ sampai 1 untuk pernyataan positif, dan 1 sampai 5 untuk pernyataan negatif.

\section{Teknik Analisis Data}

Analisis faktor merupakan salah satu teknik statistik multivariate yang bertujuan untuk mengelompokkan data menjadi beberapa kelompok sesuai dengan korelasi antar variabel. Pada aplikasi penelitian, analisis factor dapat digunakan untuk mengetahui pengelompokan individu sesuai dengan karakteristiknya, maupun untuk menguji validitas konstruk.

Dalam analisis faktor, tidak ada variabel dependen dan independen. Proses analisis factor sendiri mencoba menemukan hubungan (interrelationship) antar sejumlah faktor-faktor yang saling dependen dengan yang lain, sehingga dapat dibuat satu atau beberapa kumpulan variabel yang lebih sedikit dari jumlah awal.

Dalam penelitian ini, analisis faktor digunakan untuk:

a. Menguji validitas konstruk, dalam hal ini menguji apakah indicatorindikator yang dikonsepsikan secara unidimensional, tepat, dan konsisten dapat menjelaskan konstruk yang diteliti. Analisis faktor dapat menampilkan hasil ekstraksi butir-butir pernyataan menjadi beberapa komponen yang diinginkan peneliti. Prinsip yang digunakan sama yaitu mengelompokkan data berdasarkan interkorelasi antar butir. Sebuah butir atau item dinyatakan merupakan pembentuk faktor jika nilai korelasinya lebih besar sama dengan $(>=)$ 0,5.

b. Menguji validitas faktor. Dalam analisis ini, pengujian dilakukan untuk melihat seberapa besar korelasi antara factor satu dengan yang lain yang menjadi pembentuk variabel sehingga dapat diketahui faktor-faktor apa yang dominan membentuk variabel Kualitas Kehidupan Kerja. Jika ditemukan korelasi yang cukup kuat diantara factor-faktor pembentuk maka faktor tersebut dinyatakan memang sebagai pembentuk variabel. Besarnya matrik korelasi yang lazim digunakan adalah 0,5.

Langkah-langkah yang dilakukan dalam analisis faktor adalah:

a. Melakukan tabulasi dan pemetaan hasil kuisioner kedalam program SPSS 19.

b. Membentuk matriks korelasi, untuk mengetahui kedekatan hubungan antar butir pernyataan atau faktor yang diteliti. Dalam tahap ini terdapat dua hal yang dapat dilakukan agar analisis faktor dapat dilaksanakan. Pertama adalah menentukan nilai Barlett Test of Sphericity, yang digunakan untuk mengetahui apakah terdapat korelasi yang signifikan antar konstruk atau antar faktor. Kedua, dengan 
melihat Keiser Meyers Oklin (KMO) Measure of Sampling Adequacy, yang digunakan untuk mengukur kecukupan sampel dengan cara membandingkan besarnya koefisien korelasi yang diamati dengan koefisien parsialnya. Kriteria yang digunakan untuk menilai besaran nilai Barlett Test of Sphericity dan nilai Keiser Meyers Oklin Measure of Sampling Adequacy (KMOMSA) adalah lebih besar dari 0,5 agar analisis faktor dapat dilanjutkan. Apabila nilai KMOMSA kurang dari 0,5 maka butir pernyataan atau faktor tersebut dikeluarkan dari analisis selanjutnya.

c. Melakukan ekstraksi faktor terhadap sekumpulan butir pernyataan atau faktor yang memiliki KMO-MSA lebih besar dari 0,5 sehingga terbentuk satu atau lebih komponen inti atau variabel. Metode yang digunakan untuk ekstraksi faktor adalah Principal Component Analysis yang akan menghasilkan nilai Eigenvalue. Butir pernyataan atau faktor dapat dikelompokkan ke dalam satu atau lebih komponen dimana Eigenvalue yang diperoleh lebih besar dari satu.

d. Melakukan rotasi faktor yang menghasilkan nilai communalities yang menunjukkan besarnya kontribusi masing-masing faktor terhadap komponen yang terbentuk dan faktor loading yang menunjukkan besarnya korelasi antara suatu komponen dengan faktor pembentuknya. Proses pengelompokan faktor ke dalam komponen dilakukan dengan membandingkan besarnya korelasi pada masing-masing faktor untuk setiap komponen yang terbentuk. Selanjutnya masing-masing komponen yang terbentuk selanjutnya disebut sebagai variabel dan diberikan nama sesuai dengan faktor-faktor yang membentuknya.

\section{PEMBAHASAN}

Pada bab ini dijelaskan mengenai gambaran data penelitian yang diperoleh dari hasil jawaban responden terhadap faktor-faktor yang menentukan kualitas kehidupan kerja karyawan di Fakultas Ekonomi Universitas Negeri Jakarta. Data primer yang diperoleh melalui instrumen penelitian berupa kuisioner dikembangkan untuk mengukur variabel kualitas kehidupan kerja. Instrumen penelitian untuk mengukur kualitas kehidupan kerja memiliki jumlah item pernyataan sebanyak 45 butir. Tabel 1 menjelaskan tentang jumlah item pada masing-masing faktor yang dikembangkan untuk mengukur kualitas kehidupan kerja.

Analisis faktor yang pertama dilakukan bertujuan untuk menguji validitas konstruk (indikator) terhadap setiap butir pernyataan. Langkah pertama yang dilakukan untuk menguji validitas konstruk (indikator) adalah membentuk matrik korelasi, yang merupakan matrik yang memuat koefisien korelasi dari semua butir pernyataan yang digunakan untuk mengukur variabel kualitas kehidupan kerja. Dengan menggunakan matrik 
korelasi dapat diketahui kedekatan hubungan antar butir pernyataan. Berdasarkan hasil analisis korelasi dapat diketahui hasil ekstraksi butirbutir pernyataan menjadi beberapa faktor yang diinginkan peneliti. Prinsip yang digunakan yaitu mengelompokkan data berdasarkan interkorelasi antar butir. Sebuah butir/item dinyatakan merupakan pembentuk faktor jika nilai korelasinya lebih besar atau sama dengan 0,5 .

Tabel 1

Kisi-Kisi Instrumen Penelitian

\begin{tabular}{|c|c|c|}
\hline No & Faktor & $\begin{array}{l}\text { Nomor butir } \\
\text { pernyataan }\end{array}$ \\
\hline 1. & $\begin{array}{l}\text { Keseimbangan antara pekerjaan dengan } \\
\text { kehidupan di luar pekerjaan (Balance between } \\
\text { life and non life) }\end{array}$ & No butir $1,2,3,4,5,6,7$ \\
\hline 2. & Pekerjaan itu sendiri ( The work Itself) & $\begin{array}{l}\text { No butir } 8,9,10,11,12, \\
13,14\end{array}$ \\
\hline 3. & Pengembangan ketrampilan (Skill utilization) & No butir $15,16,17,18,19$ \\
\hline 4. & Lingkungan kerja (working condition) & No butir $20,21,22,23$, \\
\hline 5. & Keterlibatan Kerja (Job involvement) & No butir $24,25,26,27,28$ \\
\hline 6. & $\begin{array}{l}\text { Hubungan dengan rekan kerja (co worker } \\
\text { relationship) }\end{array}$ & No butir $29,30,31,32,33$ \\
\hline 7. & Kesempatan promosi (promotion) & No butir $34,35,36$ \\
\hline 8. & Gaji (salary) & No butir $37,38,39,40$ \\
\hline 9. & Pengawasan (Supervisors) & No butir $41,42,43,44,45$ \\
\hline
\end{tabular}

Dari hasil analisis diperoleh nilai Kaiser-Meyer-Olkin Measure of Sampling Adequacy (KMO-MSA) sebesar 0,563. Hasil ini menunjukkan bahwa instrumen yang digunakan dalam penelitian ini valid karena nilai KMO melebihi dari 0,5. Disamping itu, dilihat dari nilai Bartlett's Test menunjukkan nilai 1869,831 dengan signifikansi 0,000 maka dapat disimpulkan bahwa ada korelasi yang sangat signifikan antar butir pernyataan, sehingga dapat dinyatakan bahwa instrumen penelitian ini telah memenuhi syarat validitas.

Tabel 2

KMO and Bartlett's Test

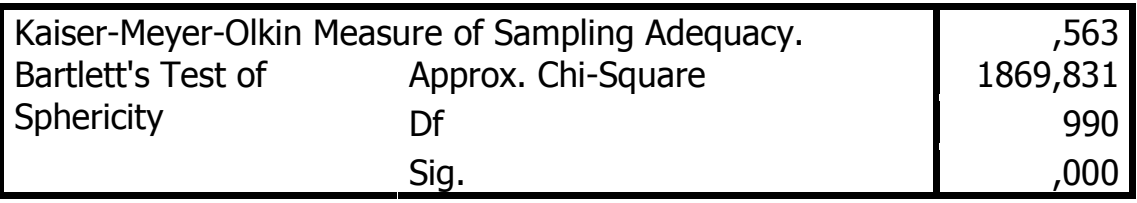


Sumber: data primer diolah, 2011

Apabila KMO sudah memenuhi syarat untuk dianalisis pada tahap selanjutnya, maka dilakukan perhitungan koefisien Measure of Sampling Adequacy (MSA) untuk masing-masing butir pernyataan yang mengukur masing- masing faktor yang kemudian disusun untuk mengukur variabel. Agar analisis lanjutan dapat dilaksanakan, koefisien MSA untuk masing-masing variabel harus lebih besar dari $(>)$ 0,5 .

Tabel 3

Anti Image Correlation

\begin{tabular}{|c|c|c|c|c|c|}
\hline No & Keterangan & Nilai & No & Keterangan & Nilai \\
\hline 1. & Butir 1 & $0.442 *$ & 26. & Butir 26 & 0.460* \\
\hline 2. & Butir 2 & 0.580 & 27. & Butir 27 & 0.662 \\
\hline 3. & Butir 3 & 0.511 & 28. & Butir 28 & $0.261^{*}$ \\
\hline 4. & Butir 4 & 0.270* & 29. & Butir 29 & 0.618 \\
\hline 5. & Butir 5 & 0.603 & 30. & Butir 30 & 0.733 \\
\hline 6. & Butir 6 & 0.691 & 31. & Butir 31 & 0.585 \\
\hline 7. & Butir 7 & 0.664 & 32. & Butir 32 & $0.417 *$ \\
\hline 8. & Butir 8 & 0.651 & 33. & Butir 33 & 0.563 \\
\hline 9. & Butir 9 & 0.586 & 34. & Butir 34 & 0.731 \\
\hline 10. & Butir 10 & 0.522 & 35. & Butir 35 & 0.688 \\
\hline 11. & Butir 11 & 0.568 & 36. & Butir 36 & 0.543 \\
\hline 12. & Butir 12 & 0.567 & 37. & Butir 37 & $0.306^{*}$ \\
\hline 13. & Butir 13 & 0.334* & 38. & Butir 38 & $0.425^{*}$ \\
\hline 14. & Butir 14 & $0.400 *$ & 39. & Butir 39 & $0.459 *$ \\
\hline 15. & Butir 15 & 0.429* & 40. & Butir 40 & $0.180 *$ \\
\hline 16. & Butir 16 & 0.580 & 41. & Butir 41 & 0.680 \\
\hline 17. & Butir 17 & 0.634 & 42. & Butir 42 & 0.722 \\
\hline 18. & Butir 18 & 0.584 & 43. & Butir 43 & $0.421^{*}$ \\
\hline 19. & Butir 19 & 0.276* & 44. & Butir 44 & 0.722 \\
\hline 20. & Butir 20 & 0.508 & 45. & Butir 45 & 0.748 \\
\hline 21. & Butir 21 & 0.590 & & & \\
\hline 22. & Butir 22 & 0.664 & & & \\
\hline 23. & Butir 23 & 0.575 & & & \\
\hline 24. & Butir 24 & 0.556 & & & \\
\hline 25. & Butir 25 & 0.791 & & & \\
\hline
\end{tabular}

Sumber: data primer diolah, 2011

Tabel 3 menunjukkan korelasi anti image setiap butir pernyataan yang disebut dengan koefisien MSA. Butir pernyataan dengan MSA kurang 
dari $\quad(<) \quad 0,5$ merupakan butir pernyataan yang harus dikeluarkan dari instrumen, untuk selanjutnya dilakukan analisis ulang sampai KMO memenuhi syarat.

Berdasarkan tabel 4.3 dapat diketahui bahwa dari 45 butir pernyataan yang digunakan untuk mengukur variabel kualitas kehidupan kerja, terdapat 14 butir pernyataan yang memiliki nilai koefisien MSA kurang dari 0,5 (diberikan tanda *) yaitu butir pernyataan no $1,4,13$, $14,15,19,26,28,32,37,38,39,40$ dan 43. Butir pernyataan tersebut selanjutnya dikeluarkan dari analisis yang dilakukan berikutnya karena tidak memenuhi syarat kriteria yang digunakan untuk menguji validitas konstruk.

Berdasarkan hasil uji validitas konstruk dengan menggunakan analisis faktor dapat diketahui bahwa faktor gaji dihilangkan dalam analisis selanjutnya karena semua butir pernyataan yang ada pada faktor ini tidak valid. Empat butir yang terdapat dalam faktor gaji memiliki nilai MSA kurang dari 0,5 sehingga yang faktor gaji diekstraksi atau dikeluarkan dalam analisis selanjutnya.

Tabel 4

Kisi-Kisi Instrumen Penelitian

\begin{tabular}{|c|c|c|c|}
\hline No & Faktor & $\begin{array}{l}\text { Nomor butir } \\
\text { pernyataan }\end{array}$ & $\begin{array}{l}\text { No butir pernyataan } \\
\text { setelah uji validitas }\end{array}$ \\
\hline 1. & $\begin{array}{l}\text { Keseimbangan antara } \\
\text { pekerjaan dengan } \\
\text { kehidupan di luar pekerjaan } \\
\text { (Balance between life and } \\
\text { non life) }\end{array}$ & $\begin{array}{l}\text { No butir } 1^{*}, 2,3 \text {, } \\
4 *, 5,6,7\end{array}$ & No butir $1,2,3,4,5$ \\
\hline 2. & $\begin{array}{l}\text { Pekerjaan itu sendiri (The } \\
\text { work Itself) }\end{array}$ & $\begin{array}{l}\text { No butir } 8,9,10, \\
11,12,13^{*}, 14^{*}\end{array}$ & No butir $6,7,8,9,10$ \\
\hline 3. & $\begin{array}{l}\text { Pengembangan ketrampilan } \\
\text { (Skill utilization) }\end{array}$ & $\begin{array}{l}\text { No butir } 15^{*}, 16 \text {, } \\
17,18,19^{*}\end{array}$ & No butir $11,12,13$ \\
\hline 4. & $\begin{array}{l}\text { Lingkungan kerja (working } \\
\text { condition) }\end{array}$ & $\begin{array}{l}\text { No butir 20, 21, } \\
22,23,\end{array}$ & No butir $14,15,16,17$ \\
\hline 5. & \begin{tabular}{|lll}
$\begin{array}{l}\text { Keterlibatan } \\
\text { involvement) }\end{array}$ & Kerja & (Job \\
\end{tabular} & $\begin{array}{l}\text { No butir } 24,25, \\
26 *, 27,28^{*}\end{array}$ & No bu \\
\hline 6. & $\begin{array}{l}\begin{array}{l}\text { Hubungan dengan } \\
\text { kerja (cokan } \\
\text { relationship) }\end{array} \text { worker } \\
\end{array}$ & $\begin{array}{l}\text { No butir } 29,30, \\
31,32 * 33\end{array}$ & No butir $21,22,23,24$ \\
\hline 7. & $\begin{array}{l}\text { Kesempatan } \\
\text { (promotion) }\end{array}$ & $\begin{array}{l}\text { No butir 34, 35, } \\
36\end{array}$ & No butir $25,26,27$ \\
\hline 8. & Gaji (salary) & $\begin{array}{l}\text { No butir } 37^{*}, 38^{*}, \\
39^{*}, 40^{*}\end{array}$ & Dihilangk \\
\hline 9. & Pengawasan (Supervisors) & No butir 41,42 , & No butir $28,29,30,31$ \\
\hline
\end{tabular}


Umi Widyastuti \& Dedi Purwana: Analisis Faktor-Faktor Dalam Kualitas Kehidupan Kerja di Fakultas Ekonomi Universitas Negeri Jakarta

\begin{tabular}{|l|l|l|}
\hline & $43 *, 44,45$ \\
\hline
\end{tabular}

Untuk tahapan selanjutnya jumlah butir pernyataan yang dapat dianalisis menjadi berjumlah 31 butir. Jika butir pernyataan tersebut dikategorikan berdasarkan faktorfaktor yang dikembangkan dalam penelitian ini maka diperoleh 8 faktor yaitu keseimbangan antara pekerjaan dengan kehidupan di luar pekerjaan, pekerjaan itu sendiri, pengembangan ketrampilan dan kesempatan untuk maju, lingkungan kerja, keterlibatan kerja, hubungan dengan rekan kerja, kesempatan promosi dan pengawasan. Tabel 4.4 menjelaskan tentang pengelompokan nomor butir pernyataan kedalam masing-masing faktor yang dikembangkan dalam penelitian ini setelah dilakukan uji validitas konstruk terhadap instrumen tersebut.
Selanjutnya $31 \quad$ butir pernyataan yang telah memenuhi syarat validitas tersebut, dilakukan analisis ulang untuk menghitung Kaiser-Meyer-Olkin Measure of Sampling Adequacy (KMO-MSA) dan Bartlet's Test. Berdasarkan hasil perhitungan SPSS 19 maka diketahui bahwa nilai Kaiser-Meyer-Olkin Measure of Sampling Adequacy (KMO-MSA) mengalami peningkatan menjadi 0,721 yang artinya kecukupan sampel yang digunakan dalam penelitian ini cukup memuaskan. Dan nilai Bartlet's Test sebesar 1231,361 dengan signifikansi 0.000 menunjukkan terdapat korelasi yang sangat signifikan antar butir pernyataan dalam instrumen tersebut (lihat tabel 5).

Tabel 5

KMO and Bartlett's Test

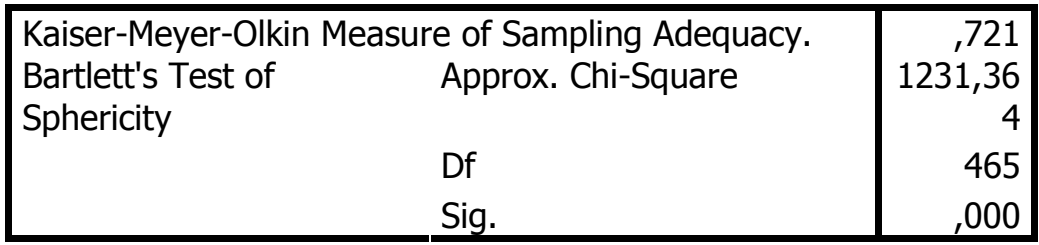

Sumber : data primer diolah, 2011

Tahap berikutnya adalah melakukan perhitungan koefisien Measure of Sampling Adequacy (MSA) untuk masing-masing butir pernyataan untuk mengetahui apakah variabel tersebut masih dapat diprediksi dan dianalisis lebih lanjut.
Berdasarkan perhitungan anti image correlation dengan menggunakan software SPSS 19 diperoleh nilai MSA untuk masing-masing butir pernyataan, seperti yang disajikan dalam tabel 6 .

Tabel 6

Anti Image Correlation

\begin{tabular}{|c|c|c|c|c|c|}
\hline No & Keterangan & Nilai & No & Keterangan & Nilai \\
\hline 1. & Butir 1 & 0.677 & 17. & Butir 17 & 0.826 \\
\hline
\end{tabular}




\begin{tabular}{|c|c|c|c|c|c|}
\hline 2. & Butir 2 & $0.486 *$ & 18. & Butir 18 & 0.680 \\
\hline 3. & Butir 3 & 0.784 & 19. & Butir 19 & 0.856 \\
\hline 4. & Butir 4 & 0.732 & 20. & Butir 20 & 0.762 \\
\hline 5. & Butir 5 & 0.766 & 21. & Butir 21 & 0.643 \\
\hline 6. & Butir 6 & 0.728 & 22. & Butir 22 & 0.707 \\
\hline 7. & Butir 7 & 0.682 & 23. & Butir 23 & 0.823 \\
\hline 8. & Butir 8 & 0.629 & 24. & Butir 24 & 0.705 \\
\hline 9. & Butir 9 & 0.627 & 25. & Butir 25 & 0.779 \\
\hline 10. & Butir 10 & 0.714 & 26. & Butir 26 & 0.766 \\
\hline 11. & Butir 11 & 0.784 & 27. & Butir 27 & 0.763 \\
\hline 12. & Butir 12 & 0.598 & 28. & Butir 28 & 0.713 \\
\hline 13. & Butir 13 & 0.661 & 29. & Butir 29 & 0.804 \\
\hline 14. & Butir 14 & 0.593 & 30. & Butir 30 & 0.849 \\
\hline 15. & Butir 15 & 0.629 & 31. & Butir 31 & 0.725 \\
\hline 16. & Butir 16 & 0.668 & \multicolumn{4}{|l}{} \\
\hline
\end{tabular}

Sumber: data primer diolah, 2011

Berdasarkan tabel diatas dapat diketahui bahwa dari 31 butir pernyataan yang digunakan untuk mengukur variabel kualitas kehidupan kerja, terdapat 1 (satu) butir pernyataan yang memiliki nilai koefisien MSA kurang dari 0,5 (diberikan tanda ${ }^{*}$ ) yaitu butir pernyataan nomor 2 (dua) dengan nilai MSA sebesar 0.486 . Butir pernyataan tersebut selanjutnya dikeluarkan dari analisis yang dilakukan berikutnya karena tidak memenuhi syarat kriteria yang digunakan untuk menguji validitas konstruk. Berdasarkan hasil uji validitas konstruk tersebut dapat diketahui bahwa pernyataan nomor dua tentang "saya seringkali harus membawa pekerjaan di kantor untuk diselesaikan di rumah" yang digunakan untuk mengukur faktor keseimbangan antara pekerjaan dengan kehidupan di luar pekerjaan, terbukti tidak valid sehingga untuk analisis selanjutnya butir tersebut dikeluarkan dari instrumen. Dengan demikian jumlah butir pernyataan yang memenuhi syarat uji validitas adalah 30 butir. Penjelasan mengenai pengelompokan butir pernyataan ke dalam masing-masing faktor dapat dilihat pada tabel 7 .

Tabel 7

Kisi-Kisi Instrumen Penelitian

\begin{tabular}{|c|lr|l|c|}
\hline No & \multicolumn{2}{|c|}{ Faktor } & \multicolumn{1}{c|}{$\begin{array}{l}\text { Nomor butir } \\
\text { pernyataan }\end{array}$} & $\begin{array}{l}\text { No butir pernyataan } \\
\text { setelah uji validitas }\end{array}$ \\
\hline 1. & $\begin{array}{l}\text { Keseimbangan antara } \\
\text { pekerjaan } \\
\text { kehidupan dengan di luar }\end{array}$ & $\begin{array}{l}\text { No butir 1, 2*, 3, 4, } \\
5\end{array}$ & No butir 1, 2, 3, 4, \\
\hline
\end{tabular}


Umi Widyastuti \& Dedi Purwana: Analisis Faktor-Faktor Dalam Kualitas Kehidupan Kerja di Fakultas Ekonomi Universitas Negeri Jakarta

\begin{tabular}{|c|l|l|l|}
\hline & $\begin{array}{l}\text { pekerjaan (Balance } \\
\text { between life and non } \\
\text { life) }\end{array}$ & \\
\hline 2. & $\begin{array}{l}\text { Pekerjaan itu sendiri } \\
\text { (The work Itself) }\end{array}$ & No butir 6, 7, 8, 9, 10 & No butir 5, 6, 7, 8, 9 \\
\hline 3. & $\begin{array}{l}\text { Pengembangan } \\
\text { ketrampilan (Skill } \\
\text { utilization) }\end{array}$ & No butir 11, 12,13 & No butir 10, 11, 12 \\
\hline 4. & $\begin{array}{l}\text { Lingkungan kerja } \\
\text { (working condition) }\end{array}$ & $\begin{array}{l}\text { No butir 14, 15, 16, } \\
17\end{array}$ & No butir 13, 14, 15, 16, \\
\hline 5. & $\begin{array}{l}\text { Keterlibatan Kerja (Job } \\
\text { involvement) }\end{array}$ & No butir 18, 19, 20 & No butir 17, 18, 19 \\
\hline 6. & $\begin{array}{l}\text { Hubungan dengan } \\
\text { rekan kerja (co worker } \\
\text { relationship) }\end{array}$ & No butir 21, 22, 23, & No butir 20, 21, 22, 23 \\
\hline 7. & $\begin{array}{l}\text { Kesempatan promosi } \\
\text { (promotion) }\end{array}$ & No butir 25, 26, 27 & No butir 24, 25, 26 \\
\hline 8. & $\begin{array}{l}\text { Pengawasan } \\
\text { (Supervisors) }\end{array}$ & $\begin{array}{l}\text { No butir 28, 29, 30, } \\
31\end{array}$ & No butir 27, 28, 29, 30 \\
\hline
\end{tabular}

Dari 30 butir pernyataan yang telah memenuhi syarat validitas tersebut, selanjutnya dilakukan analisis ulang untuk menghitung Kaiser-Meyer-Olkin Measure of Sampling Adequacy (KMO-MSA) dan Bartlet's Test. Berdasarkan hasil perhitungan SPSS 19 maka diketahui bahwa nilai Kaiser-Meyer-Olkin Measure of Sampling Adequacy
(KMO-MSA) mengalami peningkatan menjadi 0,728 yang artinya kecukupan sampel yang digunakan dalam penelitian ini cukup memuaskan. Dan nilai Bartlet's Test sebesar 1201,533 dengan signifikansi 0.000 menunjukkan terdapat korelasi yang sangat signifikan antar butir pernyataan dalam instrumen tersebut (lihat tabel 8).

\section{Tabel 8}

KMO and Bartlett's Test

\begin{tabular}{|ll|}
\hline Kaiser-Meyer-Olkin Measure of Sampling Adequacy. \\
Bartlett's Test of & Approx. Chi-Square \\
Sphericity & Df \\
& Sig. \\
\hline
\end{tabular}

Sumber: data primer diolah, 2011

Setelah dilakukan uji KMOMSA dan Bartlett Test maka dilakukan perhitungan anti image correlation untuk melihat koefisien Measure of
Sampling Adequacy (MSA) pada masing-masing butir pernyataan yang mengukur masing-masing faktor yang kemudian disusun untuk mengukur 
Umi Widyastuti \& Dedi Purwana: Analisis Faktor-Faktor Dalam Kualitas Kehidupan Kerja di Fakultas Ekonomi Universitas Negeri Jakarta

variabel. Perhitungan MSA ini dilakukan untuk mengetahui apakah variabel tersebut masih dapat diprediksi dan dianalisis lebih lanjut.
Berdasarkan perhitungan anti image correlation diperoleh nilai MSA untuk masing-masing butir pernyataan, seperti yang disajikan dalam tabel 9 .

Tabel 9

Anti Image Correlation

\begin{tabular}{|c|c|c|c|c|c|}
\hline No & Keterangan & Nilai MSA & No & Keterangan & Nilai MSA \\
\hline 1. & Butir 1 & 0.659 & 16. & Butir 17 & 0.823 \\
\hline 2. & Butir 2 & 0.781 & 17. & Butir 18 & 0.679 \\
\hline 3. & Butir 3 & 0.762 & 18. & Butir 19 & 0.868 \\
\hline 4. & Butir 4 & 0.777 & 19. & Butir 20 & 0.775 \\
\hline 5. & Butir 5 & 0.730 & 20. & Butir 21 & 0.639 \\
\hline 6. & Butir 6 & 0.676 & 21. & Butir 22 & 0.705 \\
\hline 7. & Butir 7 & 0.655 & 22. & Butir 23 & 0.832 \\
\hline 8. & Butir 8 & 0.621 & 23. & Butir 24 & 0.702 \\
\hline 9. & Butir 9 & 0.742 & 24. & Butir 25 & 0.778 \\
\hline 10. & Butir 10 & 0.778 & 25. & Butir 26 & 0.763 \\
\hline 11. & Butir 11 & 0.590 & 26. & Butir 27 & 0.746 \\
\hline 12. & Butir 12 & 0.665 & 27. & Butir 28 & 0.706 \\
\hline 13. & Butir 13 & 0.592 & 28. & Butir 29 & 0.802 \\
\hline 14. & Butir 14 & 0.679 & 29. & Butir 30 & 0.843 \\
\hline 15. & Butir 15 & 0.682 & 30. & Butir 31 & 0.711 \\
\hline
\end{tabular}

Sumber: data primer diolah, 2011

Berdasarkan tabel 9 dapat diketahui bahwa semua butir pernyataan yang digunakan untuk mengukur variabel kualitas kehidupan kerja memiliki nilai MSA lebih dari 0,5 . Dengan demikian semua butir tersebut telah memenuhi syarat validitas konstruk dan dapat dilakukan analisis lebih lanjut berdasarkan tahapan dalam analisis faktor.

Setelah melakukan uji validitas konstruk dengan menggunakan analisis faktor untuk mengetahui butir pernyataan yang valid dalam instrumen yang dikembangkan dalam penelitian ini, selanjutnya dilakukan analisis faktor untuk mengetahui faktor-faktor apa yang menentukan variabel kualitas kehidupan kerja. Langkah pertama yang dilakukan adalah menghitung Kaiser-Meyer-Olkin Measure of Sampling Adequacy (KMO-MSA) dan Bartlet's Test. Berdasarkan hasil perhitungan SPSS 19 maka diketahui bahwa nilai Kaiser-Meyer-Olkin Measure of Sampling Adequacy (KMO-MSA) mengalami peningkatan menjadi 0,792 yang artinya kecukupan sampel yang digunakan dalam penelitian ini cukup memuaskan. Dan nilai Bartlet's Test sebesar 175,357 dengan signifikansi 0.000 menunjukkan terdapat korelasi yang sangat signifikan antar faktor- 
Umi Widyastuti \& Dedi Purwana: Analisis Faktor-Faktor Dalam Kualitas Kehidupan Kerja di Fakultas Ekonomi Universitas Negeri Jakarta

faktor yang menentukan kualitas kehidupan kerja (lihat tabel 10). 
Tabel 10

KMO and Bartlett's Test

\begin{tabular}{ll|r|}
\hline Kaiser-Meyer-Olkin Measure of Sampling Adequacy. &, 792 \\
Bartlett's Test of $\quad$ Approx. Chi-Square & 175,357 \\
Sphericity & Df & 28 \\
& Sig. &, 000 \\
\hline
\end{tabular}

Sumber: data primer diolah, 2011

Setelah dilakukan uji KMOMSA dan Bartlett Test maka dilakukan perhitungan anti image correlation untuk melihat koefisien Measure of Sampling Adequacy (MSA) pada masing-masing faktor yang menentukan variabel kualitas kehidupan kerja. Perhitungan MSA ini dilakukan untuk mengetahui apakah variabel tersebut masih dapat diprediksi dan dianalisis lebih lanjut. Berdasarkan perhitungan anti image correlation diperoleh nilai MSA untuk masing-masing faktor, seperti yang disajikan dalam tabel 11.

Tabel 11

Anti Image Correlation

\begin{tabular}{|c|l|c|}
\hline No & \multicolumn{1}{|c|}{ Faktor } & Nilai MSA \\
\hline 1. & $\begin{array}{l}\text { Keseimbangan antara pekerjaan dengan } \\
\text { kehidupan di luar pekerjaan (Balance } \\
\text { between life and non life) }\end{array}$ & 0.795 \\
\hline 2. & Pekerjaan itu sendiri (The work Itself) & 0.832 \\
\hline 3. & Pengembangan ketrampilan (Skill utilization) & 0.624 \\
\hline 4. & Lingkungan kerja (working condition) & 0.828 \\
\hline 5. & Keterlibatan Kerja (Job involvement) & 0.788 \\
\hline 6. & $\begin{array}{l}\text { Hubungan dengan rekan kerja (co worker } \\
\text { relationship) }\end{array}$ & 0.836 \\
\hline 7. & Kesempatan promosi (promotion) & 0.766 \\
\hline 8. & Pengawasan (Supervisors) & 0.821 \\
\hline
\end{tabular}

Sumber: data primer diolah, 2011

Tabel 11 menunjukkan nilai MSA untuk masing-masing faktor memenuhi kriteria yang diharapkan yaitu lebih besar dari 0,5 yang artinya bahwa semua faktor dapat diprediksi dan dianalisis lebih lanjut. Tahap berikutnya merupakan analisis inti yang terdapat dalam analisis faktor. Dalam tahap ini dilakukan ekstraksi terhadap faktor-faktor yang memiliki MSA lebih dari 0,5 untuk mengelompokkan faktor-faktor tersebut menjadi satu atau lebih faktor. Dengan menggunakan metode Principal Component Analysis maka diperoleh nilai communalities, total variance explained dan Eigenvalue untuk masing-masing faktor seperti 
Umi Widyastuti \& Dedi Purwana: Analisis Faktor-Faktor Dalam Kualitas Kehidupan Kerja di Fakultas Ekonomi Universitas Negeri Jakarta

yang dapat dilihat dalam tabel 12 dan

tabel 13. 


\section{Tabel 12}

Communalities

\begin{tabular}{|l|l|r|}
\hline & Initial & Extraction \\
\hline VAR00001 & 1,000 &, 513 \\
VAR00002 & 1,000 &, 479 \\
VAR00003 & 1,000 &, 716 \\
VAR00004 & 1,000 &, 616 \\
VAR00005 & 1,000 &, 623 \\
VAR00006 & 1,000 &, 671 \\
VAR00007 & 1,000 &, 626 \\
VAR00008 & 1,000 &, 624 \\
\hline
\end{tabular}

Extraction Method: Principal

Component Analysis.

Tabel 12 menjelaskan nilai communalities, yaitu nilai yang menunjukkan sumbangan efektif tiap faktor terhadap komponen yang terbentuk. Untuk faktor 1 yaitu keseimbangan antara pekerjaan dengan kehidupan di luar kerja memberikan sumbangan sebesar $51,3 \%$ terhadap komponen yang terbentuk. Faktor 2 yaitu pekerjaan itu sendiri memberikan kontribusi terhadap komponen yang terbentuk sebesar $47.9 \%$. Faktor 3 yaitu pengembangan ketrampilan dan kesempatan maju memberikan kontribusi terhadap komponen yang terbentuk sebesar $71.6 \%$. Faktor 4 yaitu lingkungan kerja memberikan kontribusi terhadap komponen yang terbentuk sebesar $61.6 \%$. Faktor 5 yaitu keterlibatan kerja memberikan kontribusi sebesar $62.3 \%$ terhadap komponen yang terbentuk. Faktor 6 yaitu hubungan dengan rekan kerja memberikan sumbangan sebesar $67.1 \%$ terhadap komponen yang terbentuk. Sedangkan faktor 7 yaitu kesempatan promosi memberikan kontribusi terhadap komponen yang terbentuk sebesar $62.6 \%$. Dan faktor terakhir pengawasan memberikan kontribusi sebesar $62.4 \%$ terhadap komponen yang terbentuk.

Tabel 13

Total Variance Explained

\begin{tabular}{|l|r|r|r|r|r|r|}
\hline \multirow{2}{*}{$\begin{array}{l}\text { Comp } \\
\text { onent }\end{array}$} & \multicolumn{3}{|c|}{ Initial Eigenvalues } & \multicolumn{3}{|c|}{$\begin{array}{c}\text { Extraction Sums of Squared } \\
\text { Loadings }\end{array}$} \\
\cline { 2 - 7 } & Total & $\begin{array}{c}\text { \% of } \\
\text { Variance }\end{array}$ & Cumulative \% & Total & $\begin{array}{c}\% \text { of } \\
\text { Variance }\end{array}$ & $\begin{array}{c}\text { Cumulative } \\
\%\end{array}$ \\
\hline 1 & $\mathbf{3 , 2 5 9}$ & $\mathbf{4 0 , 7 3 9}$ & $\mathbf{4 0 , 7 3 9}$ & $\mathbf{3 , 2 5 9}$ & $\mathbf{4 0 , 7 3 9}$ & $\mathbf{4 0 , 7 3 9}$ \\
2 & $\mathbf{1 , 6 0 9}$ & $\mathbf{2 0 , 1 1 3}$ & $\mathbf{6 0 , 8 5 2}$ & $\mathbf{1 , 6 0 9}$ & $\mathbf{2 0 , 1 1 3}$ & $\mathbf{6 0 , 8 5 2}$ \\
3 &, 771 & 9,633 & 70,485 & & & \\
4 &, 566 & 7,077 & 77,562 & & & \\
5 &, 534 & 6,671 & 84,234 & & & \\
6 &, 519 & 6,483 & 90,717 & & & \\
7 &, 416 & 5,199 & 95,916 & & & \\
8 &, 327 & 4,084 & 100,000 & & & \\
\hline
\end{tabular}

Extraction Method: Principal Component Analysis. 
Tabel 13 menunjukkan bahwa setelah dilakukan ekstraksi pada kedelapan faktor yang ada maka terbentuk dua komponen inti yang memiliki nilai Eigenvalue diatas 1 yaitu komponen 1 dengan Eigenvalue 3,259 mampu menjelaskan varians total sebesar $40.739 \%$ dan komponen 2 yang memiliki eigenvalue sebesar 1,609 mampu menjelaskan varians total sebesar $20,113 \%$.

Tabel 14

Total Variance Explained

\begin{tabular}{|l|r|r|r|r|r|r|}
\hline \multirow{2}{*}{$\begin{array}{l}\text { Comp } \\
\text { onent }\end{array}$} & \multicolumn{3}{|c|}{ Initial Eigenvalues } & \multicolumn{3}{c|}{ Rotation Sums of Squared } \\
\cline { 2 - 7 } & Total & \% of Variance & $\begin{array}{c}\text { Cumulative } \\
\text { \% }\end{array}$ & Total & $\begin{array}{c}\text { \% of } \\
\text { Variance }\end{array}$ & $\begin{array}{c}\text { Cumulative } \\
\%\end{array}$ \\
\hline 1 & $\mathbf{3 , 2 5 9}$ & $\mathbf{4 0 , 7 3 9}$ & $\mathbf{4 0 , 7 3 9}$ & $\mathbf{2 , 5 4 5}$ & $\mathbf{3 1 , 8 1 7}$ & $\mathbf{3 1 , 8 1 7}$ \\
2 & $\mathbf{1 , 6 0 9}$ & $\mathbf{2 0 , 1 1 3}$ & $\mathbf{6 0 , 8 5 2}$ & $\mathbf{2 , 3 2 3}$ & $\mathbf{2 9 , 0 3 4}$ & $\mathbf{6 0 , 8 5 2}$ \\
3 &, 771 & 9,633 & 70,485 & & & \\
4 &, 566 & 7,077 & 77,562 & & & \\
5 &, 534 & 6,671 & 84,234 & & & \\
6 &, 519 & 6,483 & 90,717 & & & \\
7 &, 416 & 5,199 & 95,916 & & & \\
8 &, 327 & 4,084 & 100,000 & & & \\
\hline
\end{tabular}

Tabel 14 menjelaskan bahwa apabila dari delapan faktor yang ada direduksi menjadi satu faktor saja maka faktor tersebut mampu menjelaskan varians total sebesar $31.817 \%$. Dan jika delapan faktor tersebut direduksi kedalam dua faktor baru maka kedua faktor tersebut mampu menjelaskan varians total sebesar 60.852\%. Untuk melihat faktor apa saja yang selanjutnya dikelompokkan dalam faktor 1 dan faktor 2 maka dilakukan rotasi faktor dengan metode varimax. Rotasi faktor dengan metode varimax menghasilkan factor loading yaitu angka yang menunjukkan besarnya korelasi antara suatu variabel dengan faktor 1 , faktor 2, faktor 3 dan seterusnya sebagai faktor pembentuknya.

Tabel 15

Rotated Component Matrix ${ }^{a}$

\begin{tabular}{l|c|c|}
\hline \multirow{2}{*}{} & \multicolumn{2}{|c|}{ Component } \\
\cline { 2 - 3 } & 1 & 2 \\
\hline VAR00001 & $\mathbf{, 7 1 6}$ &, 007 \\
VAR00002 &, 076 & $\mathbf{, 6 8 8}$ \\
VAR00003 &,- 255 & $\mathbf{, 8 0 7}$ \\
VAR00004 & $\mathbf{, 6 5 4}$ &, 433 \\
VAR00005 &, 343 & $\mathbf{, 7 1 1}$ \\
VAR00006 &, 443 & $\mathbf{6 8 9}$ \\
VAR00007 & $\mathbf{7 7 2}$ &, 175 \\
VAR00008 & $\mathbf{7 9 0}$ &,- 001 \\
\hline
\end{tabular}

Berdasarkan hasil rotasi faktor dengan metode varimax, 
seperti yang ditunjukkan pada tabel 15 , dapat diketahui bahwa dari 8 (delapan) faktor yang dikembangkan untuk mengukur kualitas kehidupan kerja, diperoleh dua faktor utama atau selanjutnya disebut komponen. Komponen 1 (satu) terbentuk dari kumpulan empat faktor yaitu faktor 1 , 4, 7 dan 8. Faktor 1 yaitu keseimbangan antara pekerjaan dan kehidupan di luar pekerjaan memiliki korelasi sebagai pembentuk variabel 1 sebesar 0.716. Lingkungan kerja (faktor 4) memiliki korelasi dengan variabel 1 sebesar 0.654 , sedangkan faktor kesempatan promosi (faktor 7) memiliki korelasi dengan variabel 1 sebesar 0.772. Faktor terakhir yang membentuk variabel 1 adalah pengawasan (faktor 8) dengan korelasi sebesar 0.790. Komponen ini selanjutnya disebut lingkungan kerja (job environtment).

Komponen 2 (dua) terbentuk dari kumpulan empat faktor yaitu faktor 2, 3, 5 dan 6 . Faktor pekerjaan itu sendiri (faktor 2) merupakan pembentuk variabel 2 dengan nilai korelasi sebesar 0.688 . Pengembangan ketrampilan (faktor 3) memiliki korelasi dengan variabel 2 sebesar 0.807. Faktor berikutnya yang membentuk variabel 2 adalah keterlibatan kerja (faktor 5) dengan koefisien korelasi sebesar 0.711 dan faktor terakhir yaitu hubungan dengan rekan kerja (faktor 6) memiliki koefisien korelasi sebesar 0.689. Komponen ini selanjutnya disebut dengan kepuasan terhadap pekerjaan (job satisfaction).

\section{KESIMPULAN}

Berdasarkan hasil analisis data maka dapat disimpulkan bahwa :

1. Faktor-faktor yang menentukan kualitas kehidupan kerja diantaranya adalah keseimbangan antara pekerjaan dan kehidupan di luar pekerjaan, pekerjaan itu sendiri, pengembangan ketrampilan dan kesempatan untuk maju, lingkungan kerja, keterlibatan kerja, hubungan dengan rekan kerja, kesempatan promosi dan pengawasan.

2. Faktor gaji bukan merupakan faktor yang menentukan kualitas kehidupan kerja, ditunjukkan dengan nilai KMO-MSA kurang dari 0.5.

3. Dari delapan faktor yang menentukan variabel kualitas kehidupan kerja karyawan di Fakultas Ekonomi Universitas Negeri Jakarta dapat dibentuk dua komponen (variabel) yaitu kepuasan terhadap pekerjaan dan rekan kerja, serta komponen (variabel) yang kedua yaitu lingkungan kerja job environtment).

4. Variabel kepuasan terhadap pekerjaan terbentuk dari empat faktor yaitu pekerjaan itu sendiri, pengembangan ketrampilan, keterlibatan kerja serta hubungan dengan rekan kerja.

5. Variabel lingkungan kerja (job environtment) merupakan variabel yang terbentuk dari empat faktor antara lain keseimbangan antara pekerjaan dan kehidupan di luar pekerjaan, 
lingkungan kerja, kesempatan promosi dan pengawasan.

6. Variabel lingkungan kerja (job environtment)

Eigenvalue 3,259 mampu menjelaskan varians total sebesar $40.739 \%$ dan variabel kepuasan terhadap pekerjaan memiliki Eigenvalue sebesar 1,609 mampu menjelaskan varians total sebesar $20,113 \%$.

7. Apabila dari delapan faktor yang ada direduksi menjadi satu faktor saja maka faktor tersebut mampu menjelaskan varians total sebesar $31.817 \%$. Dan jika delapan faktor tersebut direduksi kedalam dua faktor baru maka kedua faktor tersebut mampu menjelaskan varians total sebesar $60.852 \%$.

\section{IMPLIKASI}

Berdasarkan hasil penelitian dapat diketahui bahwa faktor-faktor dalam kualitas kehidupan kerja meliputi keseimbangan antara pekerjaan dan kehidupan di luar pekerjaan, pekerjaan itu sendiri, pengembangan ketrampilan dan kesempatan untuk maju, lingkungan kerja, keterlibatan kerja, hubungan dengan rekan kerja, kesempatan promosi dan pengawasan.

Keseimbangan antara pekerjaan dan kehidupan di luar pekerjaan menjadi faktor yang menentukan kualitas kehidupan kerja, terutama dalam hal tanggung jawab di kantor tidak mencampuri tanggung jawab lain yang diperankan oleh karyawan baik di rumah atau di lingkungan masyarakat. Selain itu jam kerja yang fleksibel juga menjadi perhatian responden, sehingga konflik antar peran dapat dihindari.

Apabila ditinjau dari sudut pandang pekerjaan, maka aspek pekerjaan itu sendiri juga merupakan faktor yang menentukan kualitas kehidupan kerja. Dalam hal ini karyawan memberikan tanggapan positif terhadap hal-hal yang berkaitan dengan pekerjaan, seperti kesesuaian antara pekerjaan dengan kemampuan dan ketrampilan yang dimiliki, karyawan dihadapkan pada pekerjaan yang menantang dan menarik, kesempatan untuk mempelajari hal-hal baru, kesempatan untuk mengikuti pelatihan-pelatihan yang mendukung pelaksanaan pekerjaan dan hal-hal yang berkaitan dengan keterlibatan terhadap pekerjaan mereka.

Penilaian karyawan terhadap kesempatan promosi, hubungan dengan rekan kerja dan pengawasan serta lingkungan kerja merupakan hal yang sangat menentukan kepuasan kerja karyawan. Oleh karena itu untuk dapat memiliki kualitas kehidupan kerja yang baik, manusia dituntut untuk dapat memenuhi kebutuhannya. Apabila mengacu pada teori hierarki kebutuhan menurut Abraham Maslow, maka manusia berusaha untuk memenuhi setiap kebutuhan, baik yang sifatnya fisiologis ataupun kebutuhan yang lebih tinggi. Dan manusia cenderung berusaha memenuhi kebutuhan di tingkat yang lebih tinggi apabila kebutuhan dibawahnya telah terpenuhi.

Kualitas kehidupan kerja tidak hanya dapat terwujud manakala 
masing-masing karyawan mendapatkan kepuasan kerja, melainkan lebih dari itu. Untuk mencapai kualitas kehidupan kerja maka perlu diperhatikan faktor-faktor yang menciptakan kepuasan kerja serta kepuasan terhadap kehidupan di luar pekerjaannya.

Berdasarkan hasil analisis data diketahui bahwa dari delapan faktor yang menentukan kualitas kehidupan kerja dapat dibentuk dua variabel yaitu kepuasan kerja dan lingkungan kerja. Mengacu dari hasil tersebut maka dapat dilakukan penelitian lebih lanjut tentang pengaruh atau hubungan kedua variabel tersebut terhadap kualitas kehidupan kerja.

\section{SARAN}

Berdasarkan hasil penelitian tersebut maka hal-hal yang perlu diperhatikan oleh Fakultas Ekonomi dalam kaitannya dengan faktor-faktor yang menentukan kualitas kehidupan kerja karyawan adalah:

1. Berdasarkan tanggapan responden, diketahui bahwa keseimbangan antara pekerjaan dan kehidupan di luar pekerjaan, rata-rata responden berpendapat bahwa tanggungjawab pekerjaan seringkali mencampuri tanggungjawab di luar pekerjaan. Untuk menciptakan keseimbangan pekerjaan dan kehidupan di luar pekerjaan, FE UNJ sebaiknya perlu mengadakan kegiatan yang dapat menjembatani tanggungjawab di kantor maupun di masyarakat atau keluarga. Hal ini dapat dilakukan dengan mengadakan kegiatan yang bersifat sosial secara konsisten seperti kegiatan economics expo, family gathering dan lain-lain.

2. Fakultas Ekonomi perlu mempertimbangkan

pemberian kesempatan mengikuti pelatihan secara lebih merata. Hal ini didukung dengan hasil penelitian yang menunjukkan rata-rata responden memberikan tanggapan kurang setuju terhadap kesempatan pengembangan ketrampilan.

\section{DAFTAR PUSTAKA}

Ari Husnawati, 2006. Analisis Pengaruh Kualitas Kehidupan Kerja terhadap Kinerja Karyawan dengan Komitmen dan Kepuasan sebagai Intervening Variabel (Studi pada PERUM Pegadaian Kanwil VI Semarang, Tesis, Universitas Diponegoro, Semarang.

Danna, K. \& Griffin, R.W. 1999. Health and Well Being in The Workplace: $A$ Review and Synthetis of The Literature. Journal of Management, 25, 357-384.

David dan Edward. 1991. Quality of Work Life: Perspective and Directories, Publisher from Organizational Dynamic cs. By AMACOM. 
Dessler, Gary. 2003. Manajemen Sumber Daya Manusia: Edisi 9. New Jersey: Prentice Hall Inc.

Guna Seelan Retinam and Maimunah Ismail. 2008. Constructs of Quality of Work Life: A Perspective of Information and Technology Professionals. European Journal of Social Science. Volume 7 No 1.

Hackman, J.R., and G.R., Oldham, 1980. Work Redesign. Reading, M.A: Addison-Wesley.

Loscocco, KA and A.R. Roschelle, 1991, Influence on the Quality of Work and Non Work life:
Two Decades in Review. J. Vocational Behavior, 39: 182 225.

Raduan Che Rose, Loo See Beh, Jegak Uli, Khairuddin Idris, 2006. Quality of Work Life: Implication of Career Dimensions. Journal of Social Sciences 2 (2): 61-67.

Sirgy, M. J., Efraty, D. Siegel, P \& Lee, D. 2001. A New Measure of Quality Work Life (QoWL) Based on Need Satisfaction and Spillover Theories. Social Indicator Research, 55: 241302. 